\title{
Croatian Geoheritage Sites with the Best-Case Study Analyses Regarding Former Mining and Petroleum Activities
}

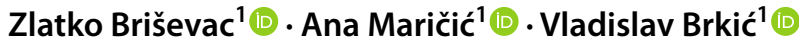

Received: 4 May 2021 / Accepted: 14 October 2021 / Published online: 27 October 2021

(c) The Author(s), under exclusive licence to The European Association for Conservation of the Geological Heritage 2021

\begin{abstract}
The revitalization and protection of industrial and natural heritage is an important part of the cultural identity of a society that respects its history and wants to build a prosperous and sustainable future. This paper describes four selected case studies of the successful revitalization and presentation of mining, geology, and petroleum heritage in the Republic of Croatia: a former quarry (Rupnica), two metal mines (St. Barbara Mine and Zrinski Mine) and one site of petroleum heritage (Peklenica and Selnica Petroleum Heritage Park). For revitalization strategy of selected areas, SWOT analysis and TOWS matrix were performed. Sub-strategy ranking was done through five key principles of geotourism. The strong and weak points of revitalized projects are indicated, as well as recommendations for the realisation of future geoheritage projects. This paper describes how a currently poor-mining country, which is intensively developing tourism, can protect, present, and promote its former industrial heritage, which is related to geoheritage. One of the main goals is to encourage all stakeholders to promote industrial heritage based on a simplified form of the mentioned analysis method and matrix.
\end{abstract}

Keywords Geotourism $\cdot$ Mining heritage $\cdot$ Petroleum heritage $\cdot$ Geoheritage $\cdot$ SWOT analysis $\cdot$ TOWS matrix

\section{Introduction}

Quarrying, mining, and petroleum extraction can be characterized as a temporary industrial activity in some places as it uses the land with a very variable duration. When a deposit is depleted or exhausted, or mining is no longer economically profitable due to the high cost of mining or low market prices, the mine must be closed and revitalized (Laurence 2011). There are many examples in the world of how post-mining land, old mines, abandoned quarries, or old petroleum sites can be revitalized and turned into new attractions and used for other purposes (Limpitlaw and Briel 2014; Mborah et al. 2016; Kaźmierczak et al. 2017; Baczyńska et al. 2018a, b; Jelen 2018; Festin et al. 2019; Kaźmierczak et al. 2019). Revitalized locations can be, and

Ana Maričić

ana.maricic@rgn.unizg.hr

Zlatko Briševac

zlatko.brisevac@rgn.unizg.hr

Vladislav Brkić

vladislav.brkic@rgn.unizg.hr

1 Faculty of Mining, Geology and Petroleum Engineering, University of Zagreb, Pierottijeva 6, 10000 Zagreb, Croatia are used, for touristic, scientific, educational, recreational, or other purposes what can influence on the increased interest and awareness of the need to protect cultural and natural values. Additionally, such places can influence local and regional development. There is a certain challenge of how to fit revitalization into desirable social movements that include ecology and sustainability. This can be done through the development of geotourism, which is a form of natural area tourism that specifically focuses on geology and landscape. It promotes tourism to geosites, the conservation of geodiversity, and an understanding of earth sciences through appreciation and learning (Dowling 2011).

Various authors consider the possibility of post-mining land revitalization, and examples of the best practices include: Wieliczka salzmine (Rybár and Hronček 2017) and Zloty Stok Gold Mine from Poland (Kaźmierczak et al. 2019), Lavrion Technological and Cultural Park in Greece (Cheirchanteri 2019), Lousal Mine in Portugal (Inácio et al. 2013), Parque de Minero de Riotinto (Pardo Abad 2017) and La Tortilla Mine in Linares from Spain (Kaźmierczak et al. 2019), and others. In addition, there are examples of petroleum and gas museums in Europe with the first National Museum of Oil Industry opened in Ploesti in Romania in 1957 (Kruczek and Kruczek 2016). Many examples of good 
revitalization practices in the world are shown on different lists, such as the UNESCO World Heritage List (URL1 2021) or the European Route of Industrial Heritage-ERIH (URL2 2021). In addition, the ongoing project "Mine Heritage: Historical Mining-Tracing and Learning from Ancient Materials and Mining Technology", funded by European Institute of Innovation and Technology-EIT (URL3 2021), oversees a database of old mining sites in eleven European countries, including Croatia.

The exploitation and production of raw materials and hydrocarbons through history have had an extensive impact on the development of economic and social conditions and influenced many industrial changes in Croatia. Throughout history, the exploitation of various raw materials has been very significant and intensive (Briševac et al. 2021). These include natural building stone (Crnković and Jovičić 1993; Fio Firi and Maričić 2020), coal (Vujec 1996), bauxite (Marušić et al. 1993), silver, lead, iron and copper ore (Vasiljević and Fabijanec 2016), bitumen (Šebečić 1995), barite, and bentonite (Crnički and Šinkovec 1993). In Croatia, a long tradition of oil and gas production, whether onshore or offshore in the Adriatic Sea, is also cherished (Križ et al. 2008). Unfortunately, over time, traces of the rich mining history are fading, and even disappearing, and only rare memories of such periods remain. In Croatia, many mining sites were abandoned and neglected without any potential plan of revitalization. Even if the plans exist, revitalization is often questionable, resulting in old mining sites to become damaged and even dangerous (Briševac et al. 2021). Croatian examples of protection and local employment of mining and petroleum heritage are not as known worldwide as those from other European countries (Poland, Spain, UK, Portugal, etc.).

An essential prerequisite for choosing the appropriate strategy of mining site revitalization is to analyze the current situation. The simplest and most easily applied tool for conducting this examination is the SWOT analysis. Although ideas of a similar concept were present during the consideration of several scientists from Stanford and Harvard Universities, the SWOT analysis was described by Learned et al. (1969). Today, it is considered a key tool for resolving complex strategic situations to improve decisionmaking. Basically, this analysis identifies the strengths and weaknesses as internal factors, and opportunities and threats as external factors. In order to analyze the different relationships between external and internal factors and form a future strategy, the concept of TOWS matrices was developed (Weihrich 1982). Besides, SWOT analysis can equally be used in all other cases to evaluate the situation and to select the most appropriate decision for the revitalization of old mining sites (Kalantari et al. 2011; Carrión Mero et al. 2018). SWOT analysis can be performed separately in a simpler form, but it can also be a part of more complex analyses as Datta (2020) showed through the TOWS matrix and Analytical Hierarchy Process on the Mama Bhagne Pahar site in India.

This paper aims to apply the SWOT analysis with a TOWS matrix and sub-strategy devising on four selected mining and petroleum sites from Croatia that represent geoheritage. In that way, such analysis could be appropriate tool for decision-making about future successful revitalization processes. Especially, it can be useful for different types of heritage, like industrial (mining and petroleum) or geological associated with mining as innovative way of revitalization. In such way, different revitalization strategies that are acceptable for touristic and especially geotouristic purposes could be devised.

\section{Best Practice Sites in Croatia-Case Studies}

Croatia has successfully revitalized several places of its geological and mining heritage mostly in the continental part (Briševac et al. 2021), but the Croatian coastal part is mainly focused on traditional mass tourism. The coastal part could use the geoheritage in a more socially acceptable way for tourism purposes. The conditions for this are there, because in 2019, for example, Geopark Vis Archipelago was also proclaimed as part of UNESCO Global Geopark Network (URL4 2021). All this offers a new opportunity to look for an interesting tourist offer, or a variety of attractions where natural, cultural and historical heritage can be combined. Therefore, the presentation of industrial heritage fits well with these trends and such brands should not be invented.

Despite the long mining tradition, examples of protection and conservation of old mining sites are equally rare with the most famous St. Barbara Mine and Zrinski Mine, both near Zagreb (Vrkljan 2019). St. Barbara Mine is an old copper and iron mine that has been revitalized by the strong engagement of residents through the Croatian Folklore Ensemble Oštrc (URL5 2021), while the old silver mine Zrinski was revitalized by the strong engagement of the Public institution Nature Park Medvednica. Other important best practice examples are the old quarry Rupnica on Papuk Mountain which represents geological heritage and is part of UNESCO Global Geoparks, and Peklenica and Selnica Petroleum Heritage Park. Their importance is in the sense that they all represent best practice examples of the revitalization of old mining and petroleum sites. Today, they are part of cultural and/or geological heritage. An extensive analysis of Croatian geological and industrial heritage was done by Briševac et al. (2021). An outline of the four selected heritage cases is shown in Table 1 with their geographical locations in Fig. 1. All of the best practice sites are described according to their geological or mining heritage relevance. 
Table 1 Outline of the selected Croatian case studies

\begin{tabular}{|c|c|c|c|}
\hline Case studies location & Geographical position & Current function & Stakeholders \\
\hline 1. Rupnica & Papuk Mountain & Abandoned quarry & Public institution-Nature Park \\
\hline 2. St. Barbara Mine & $\begin{array}{l}\text { Rude village near the } \\
\text { city of Samobor }\end{array}$ & Old mine & $\begin{array}{l}\text { Croatian Folklore Ensemble } \\
\text { Oštrc, local residents }\end{array}$ \\
\hline 3. Zrinski Mine & Medvednica Mountain & Old mine & Public institution-Nature Park \\
\hline $\begin{array}{l}\text { 4. Peklenica and Selnica } \\
\text { Petroleum Heritage } \\
\text { Park }\end{array}$ & Međimurje region & Oil depleted fields & Local residents \\
\hline
\end{tabular}

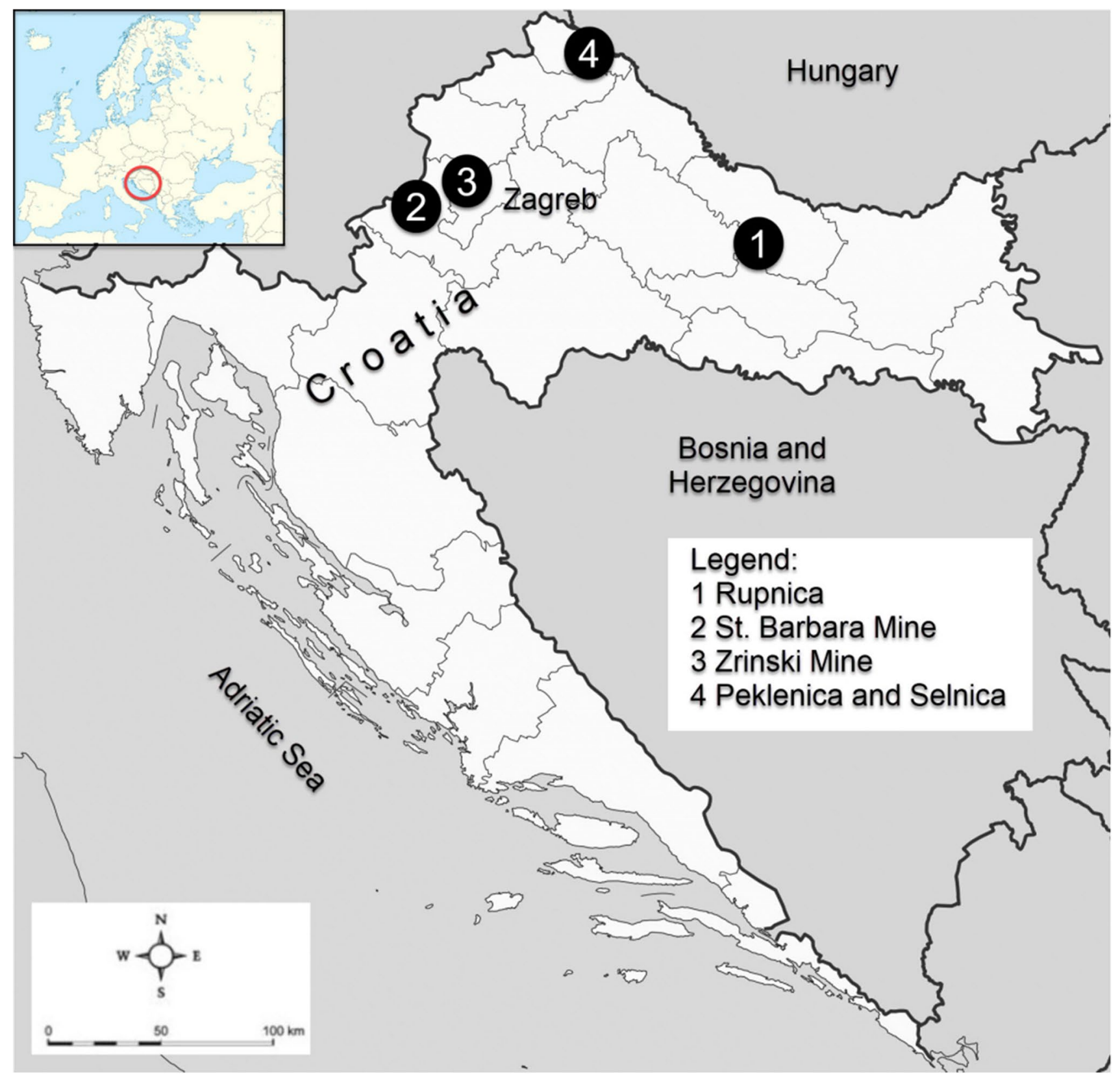

Fig. 1 Geographical location of the four studied/selected heritage sites 


\section{Rupnica Site}

The Rupnica site is situated (Fig. 1-location 1) in the eastern part of Croatia (Slavonia), on Papuk Mt., near small village Voćin. It is an old, abandoned quarry where crushed stone was excavated. Nowadays, Rupnica (Fig. 2a) is a unique geological site in Croatia, famous worldwide, due to its fascinating geological history. Rupnica is situated in the Papuk Nature Park and is a part of the Papuk Geopark, the first Croatian Geopark (URL6 2021), proclaimed in 2007, given the fact that it is extremely rich in various geological phenomena. Rupnica was protected in 1949 as the first Geological Monument of Nature because of a four- and six-sided columnar jointing phenomenon composed of albite rhyolite (Fig. 2b). It was the first out of 52 protected geosites, and one mineral currently protected by the Nature protection law in Croatia (Paunović 1996; Zwicker et al. 2008; Mileusnić et al. 2019; Žeger Pleše and Zwicker Kompar 2019). Balen and Petrinec (2013) have analyzed petrographical, geochemical and geological data. Authors concluded that the origin of the well-exposed phenomenon of columnar jointing was developed under the combined influence of large-scale constitutional supercooling and thermal contraction processes of a (sub)surface acidic lava body, which adds to the geological and scientific value of the site.

The relationship between industrial (mining) and natural (geological) heritage is especially visible in the case of Rupnica. Thanks to the mining activities, unique geological properties of Rupnica came to life and tourists and visitors can enjoy the view of the unique columnar albite rhyolite phenomenon. The old quarry is well-preserved, maintained and easily accessible to all visitors. At the same time, an educational path with educational boards was set up. During December of 2014, volunteers from the Croatian Mountain Rescue Service (CMRS) station Orahovica (URL6 2021) in cooperation with the Public institution Papuk Nature Park jointly cleaned the old quarry Rupnica of debris and waste. This was a good example of the importance of involving different stakeholders, mostly volunteers, but also public institutions in the revitalization processes. This site is especially valuable to students from both, Faculty of Mining, Geology and Petroleum Engineering, and Faculty of Science of the University of Zagreb (Fig. 2c), as every year students visit Rupnica as part of a field trip, adding to the
Fig. 2 a Unique geological Rupnica site in a former quarry with a visible b jointing phenomenon in albite rhyolite, which is $\mathbf{c}$ an important stop for visitors and especially students during field trips
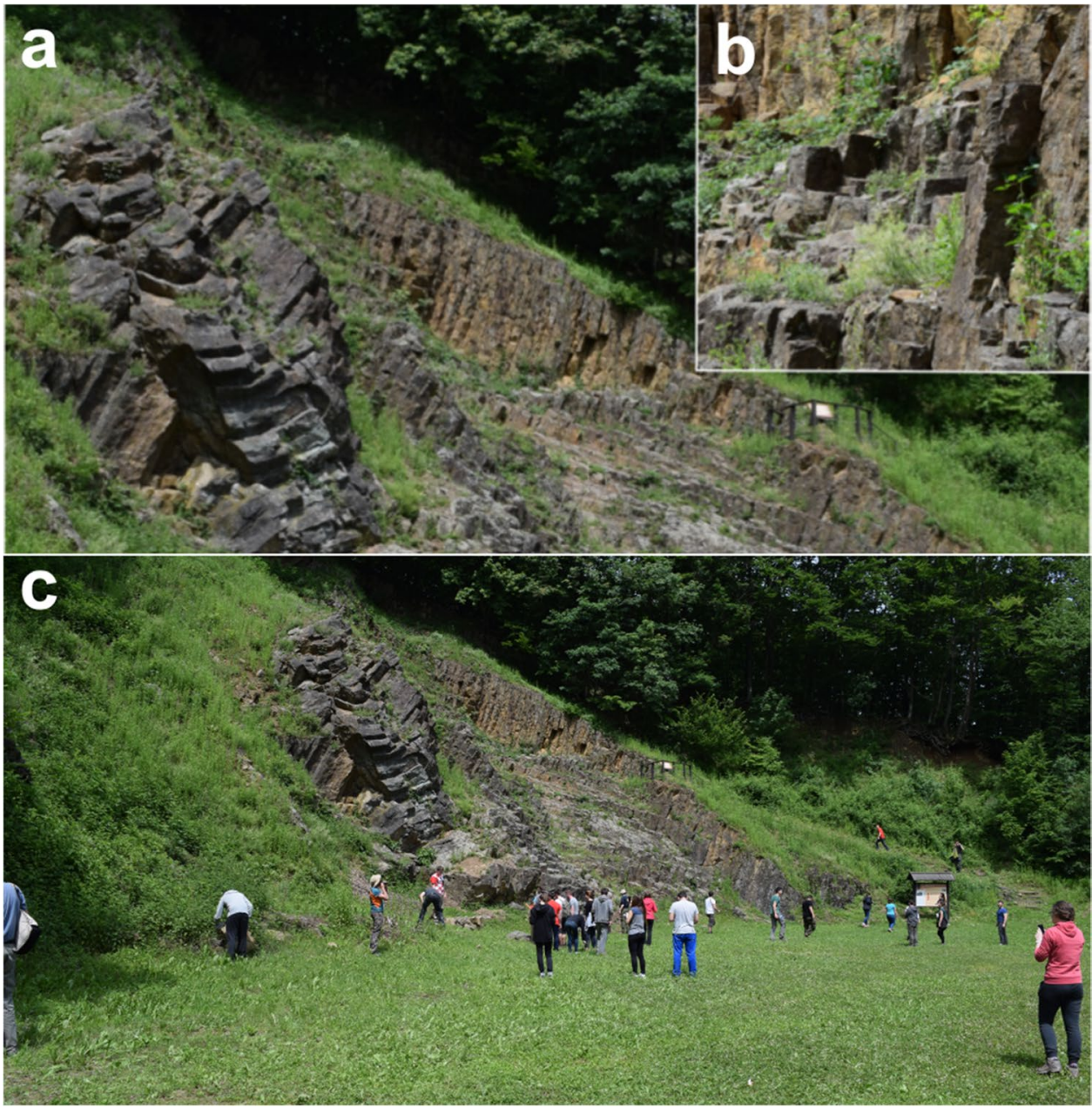
scientific and educational importance of this site. Besides students, this first geoheritage site in Croatia is important for scientists, considering that many scientific excursions and field trips were held here as part of geotourist tours. In 2020, construction of the Geo-Info Center Voćin started, funded by EU funds through the project "Geo Stories of the UNESCO Geopark" (URL6 2021). The Center is envisioned as a starting point for visitors, where they can learn about the rich geological, biological and cultural heritage of the Papuk Mountain.

\section{St. Barbara Mine}

St. Barbara Mine (Fig. 3a) is located in Rude village in the Samoborsko Gorje Hills, near the city of Samobor and the capital of Croatia, the city of Zagreb (Fig. 1-location 2). Copper, iron, and gypsum have been mined to some extent (Laszowski 1942, 1944; Šinkovec 1971). Rude deposits, according to Palinkaš et al. (2010), are a prototype of the Permian siderite-polysulphide-barite-haematite mineralization (Fig. 3b). Mineralization is hosted by Permian siliciclastic sediments below gypsum and anhydrite strata as products of rifting along the passive Gondwana margin, in the Inner Dinarides. It consists of siderite-polysulphide-barite-quartz veins, stratabound siderite-pyrite-barite-quartz ore beds, late stage barite-galena-quartz veins, stratiform haematite-barite-quartz beds and gypsum and anhydrite layers (Palinkaš et al. 2010).

The mine in this area probably existed already in Roman times. It is supposed that it was even mined during 1210. The Rude village used to be called Rovi (Laszowski 1944; Šinkovec 1971). The first official record of copper mining dates back to the year 1528 when first miners Veit Khisl, Hans Weilhammer, and Marx Stettner mined the copper (Budak 1994). During sixteenth century, copper production was significant and even reached one third of the amount of Swedish copper mine in Falun and twice the amount of the total copper production in England and four times that of Norway (Budak 1994). In the following years, iron ore was mined, but at the beginning of the nineteenth century, the production turned to gypsum, which lasted for a short time, till the 1950s. The Rude area has had a significant role in mining history since it was a stop on the copper road (Budak 1994). In addition, nearby town of Samobor was the seat of the new Mining Substitution Court from the end of 1788 to 1810 that had jurisdiction over the entire territory of Croatia and Slavonia (Petrić 2011).

In 2002, on the initiative of Prof. Boris Šinkovec, PhD, the local Croatian Folklore Ensemble Oštrc and the residents of the Rude village, the renovation of two artificially connected shafts Sveto Trojstvo and Kokel began. The renovation was partly funded through the PHARE Pre-accession Fund of the European Union. That testifies that funding and the availability of European funds for heritage conservation activities, or lack of it, are one of the main factors affecting revitalization. Besides European funds, cross-border cooperation with partners from neighbouring Croatia and Slovenia proved to be a good starting point for revitalization processes of the St. Barbara Mine. Nowadays, about 350-m-long tunnels, representing mining museums in nature, are open and accessible to visitors. There are still tunnels under the village with the main shaft Vlašić, 550-m-long, that is unfortunately collapsed (URL7 2021). Apart from the revitalization of two shafts, the project includes an educational path $(1500 \mathrm{~m}$ in length) with eight educational tables, along with a mineralogical and petrographic collection. In addition, 20 local tourist guides have been trained for leading tourist tours through the mine (Vrkljan 2019). In 2020, an interpretation centre with mining trench simulation (Fig. 3c) was built near the entrance to the mine. In addition, the first hologram installation in one mine in the World (URL8 2021) was created in the St. Barbara Mine.

St. Barbara Mine is a good example of the significance of employment and volunteerism of different actors and stakeholders, as local residents and cultural societies. Thanks to all the stakeholders involved in the revitalization processes, the St. Barbara Mine has been a part of the Register of Cultural Heritage of the Republic of Croatia since 2015-registered on the list of protected cultural properties (URL9 2021). According to the data provided by the Croatian Folklore Ensemble Oštrc, since the opening of St. Barbara Mine for tourist purposes in 2012, and till 2020, a total of 17138 visitors have visited the mine. The average number of visitors is 1900 people/year, while during 2018 and 2019, there was an increase in the number of visitors (respectively 2504 and 2815). However, in 2020, the number was drastically reduced to 1325 due to the COVID-19 pandemic. In addition, in this region, historical mining traditions are still cherished. The organization of local events related to the mining activity and local production of mining souvenirs, or even food like famous "Miners' cake" from Rude village represents an integral element of the mining heritage presentation. Miners' cake was the 29th Croatian product protected in the European Union, and every year, a manifestation called the Days of Miners' cake is organized. All this has an economic impact on the local economy.

\section{Zrinski Mine}

The Zrinski Mine is located just below the Grafičar Mountain Lodge in the area of the Medvednica Nature Park, situated near Zagreb, the capital of Croatia (Fig. 1-location 3). The beginnings of ore exploration and mining in the area of Medvednica Mountain date back to the fifteenth century. According to Belamarić (2006), the history of mining in the Zrinski Mine began when Nikola III Zrinski 
Fig. 3 a Entrance into St. Barbara Mine $\mathbf{b}$ with visible mineralization in the underground with billboard of "Bergmans" in the mine $\mathbf{c}$ new interpretation centre with mining trench simulation near entrance to the mine
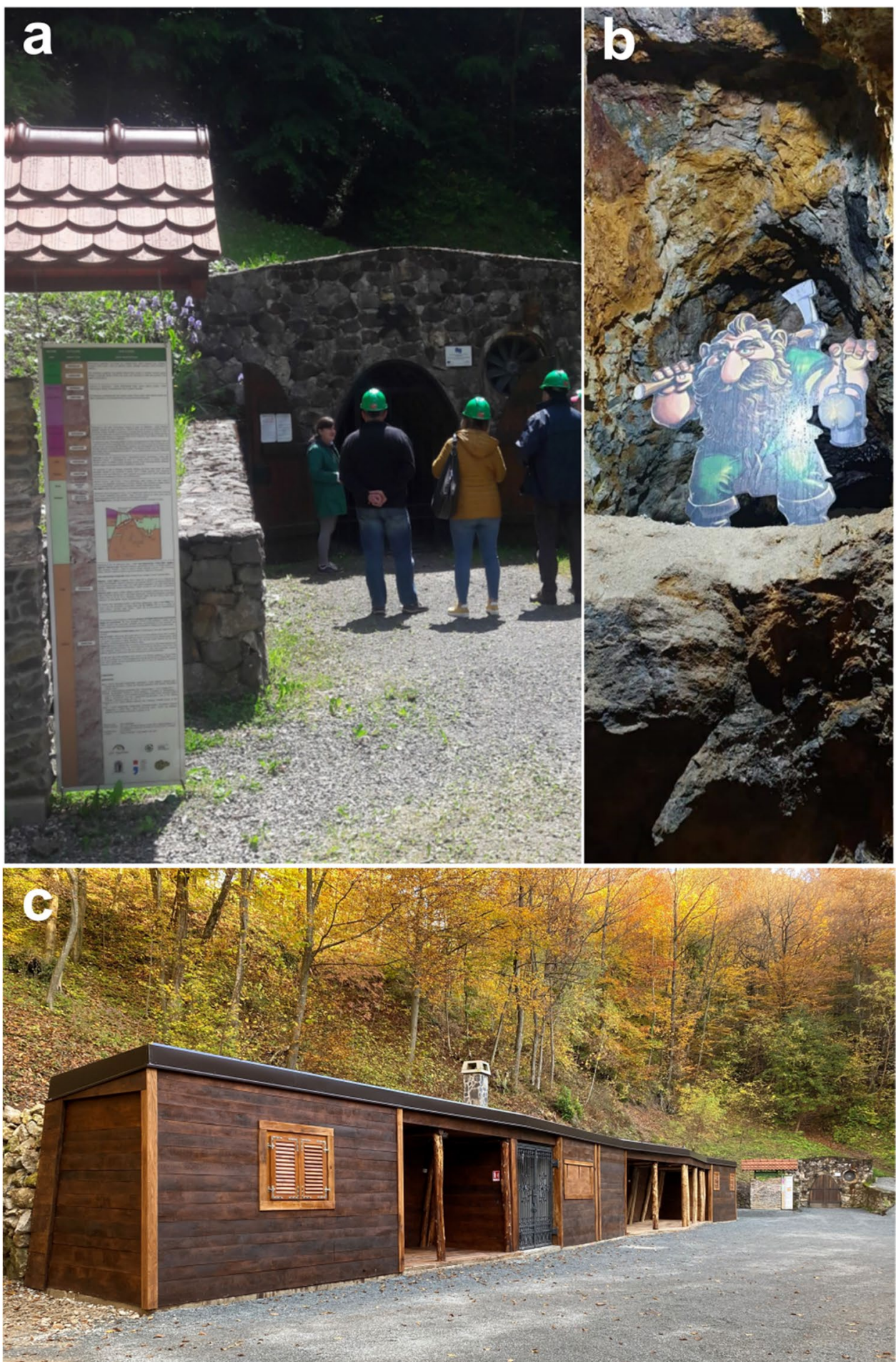

signed a contract with the people of Zagreb in 1527 and gave them the right to mine. Galena, called lead glance, as main ore mineral, was mined and silver was an admixture. Other present minerals were sphalerite, pyrite, dolomite and quartz (Šinkovec et al. 1988). This coincides with Laszowski's (1942) research who states that gold and silver mining on Medvednica began in 1608. The type of ore deposit can be better observed on the surface than in the trench, and it consists of entanglements of irregular veins, splashes and lenses of galena in dolomite (Šinkovec et al. 1988). It is interesting to note that the name of the mine is carved in a metamorphic rock-greenschist (Fig. 4a)which makes the main part of the mountain (Lugović et al. 
Fig. 4 Zrinski Mine, a the name of the mine engraved in greenschist, an b old mining tool presented at the entrance, $\mathbf{c}$ the stability of the rocks checked by the staff of the Faculty of Mining, Geology and Petroleum Engineering

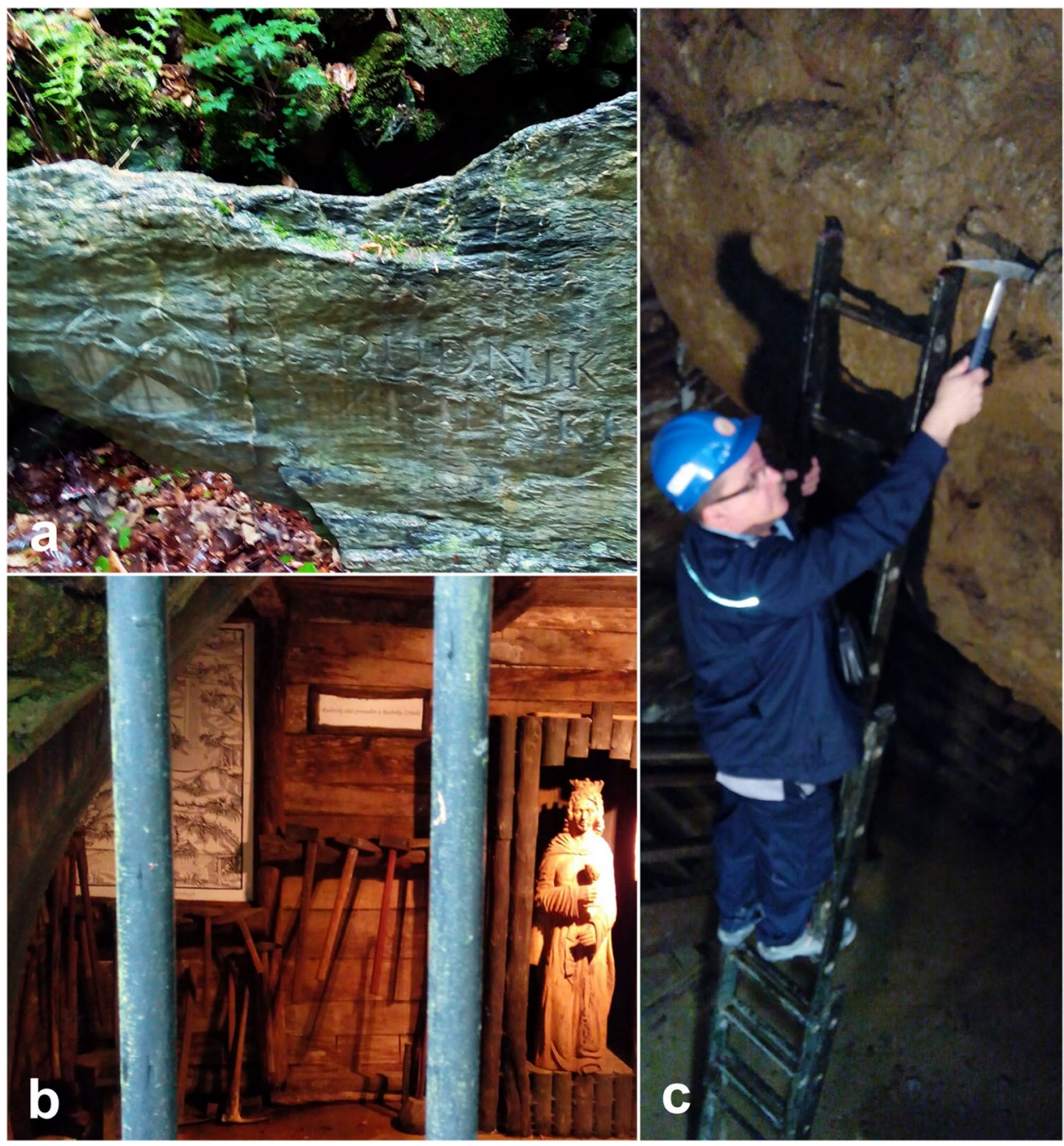

2006). Greenschist is a symbol of Medvednica, and many stone facades on buildings in Zagreb have been made of it.

Today, Zrinski Mine is a tourist attraction of the Medvednica Mountain. Its shallower parts have been revitalized. In the corridors, scenes of medieval mining were reconstructed (Vrkljan 2019) and old mining tools (Fig. 4b) are presented at the entrance. Thanks to cooperation between the Medvednica Nature Park and the Faculty of Mining, Geology and Petroleum Engineering, University of Zagreb, about a hundred meters of underground corridors were arranged for visitors and opened on St. Barbara's day in 2004 (Jug et al. 2008; Vrkljan 2019). It was proclaimed a protected cultural heritage of the Republic of Croatia in 2006. Several horizontal underground corridors, which are about $1.7 \mathrm{~m}$ high, have been carefully cleaned of collapsed material. Most of the corridors are not supported with timber as they are situated in dolomite rocks of good engineering-geological features. The rock properties and its stability are annually monitored by the staff of Faculty of Mining, Geology and Petroleum Engineering (Fig. 4c). One part of the mine that is in a fault zone is mostly ruined and not available to the visitors. With all due respect to the generations of miners and their achievements, the mine has educational purposes and visitors are invited to visit the mine and to discover a fraction of its secrets (URL10 2021).

Zrinski Mine is a part of Medvednica Nature Park, which enabled easier employment of different stakeholders in the revitalization processes. Every year, an event called Medieval Days on Medvednica near the Zrinski Mine is organized by the Medvednica Nature Park. In general, the number of mine visitors before the pandemic was 6000 annually; however, in 2020, there were 1556 visitors (URL10 2021). This represents a decline of $74 \%$, but it is reasonable to expect that the number of visitors will return to its normal level when the pandemic is over.

\section{Peklenica and Selnica Petroleum Heritage Park}

The first to extract oil in the Međimurje region (the northernmost region of Croatia) in 1856 was Count Juraj Feštetić due 
to a shaft on his property in Peklenica (Fig. 1-location 4). He was also the first to receive a permit for the exploitation of the oil field called "St. Georg", in 1860. Between 1885 and 1889, the industrialist Wilhelm Singer drilled three wells at the border of the oil field "St. Georg". These were the first oil wells in Croatia and the oldest in the world (Žgaljić 1984). Interestingly, three wooden pillars which were joined at the top were initially used to extract oil, grabbed outside with a rope. It is important to point out that at that time of the Austro-Hungarian Empire, Mining Law was applied for the exploration and production. Oil exploitation from lower part of Upper Pannonian age formation ended in 1967 due to high exploitation costs and small production. The oil had low content of paraffin which enabled its usage as a fuel without fine refining.

In 2001, an initiative for the tourist valorization of the Peklenica locality was launched and led to creation of the memorial park for petroleum mining. The memorial park perfectly reconstructs the oil extraction in the nineteenth century and is presented by an information board (Fig. 5a) and a natural oil spring (Fig. 5b).

Petroleum in Selnica has been known since 1850. Regular exploitation began in 1900 and finished in 1952. Larger oil sandstone deposits were found in two places in the Selnica area. The first is Singer's Field, where the main oil horizon is located at a depth of $165-190 \mathrm{~m}$, and the second is
Fig. 5 Peklenica Petroleum Heritage Park with a an information board and $\mathbf{b}$ a natural oil spring

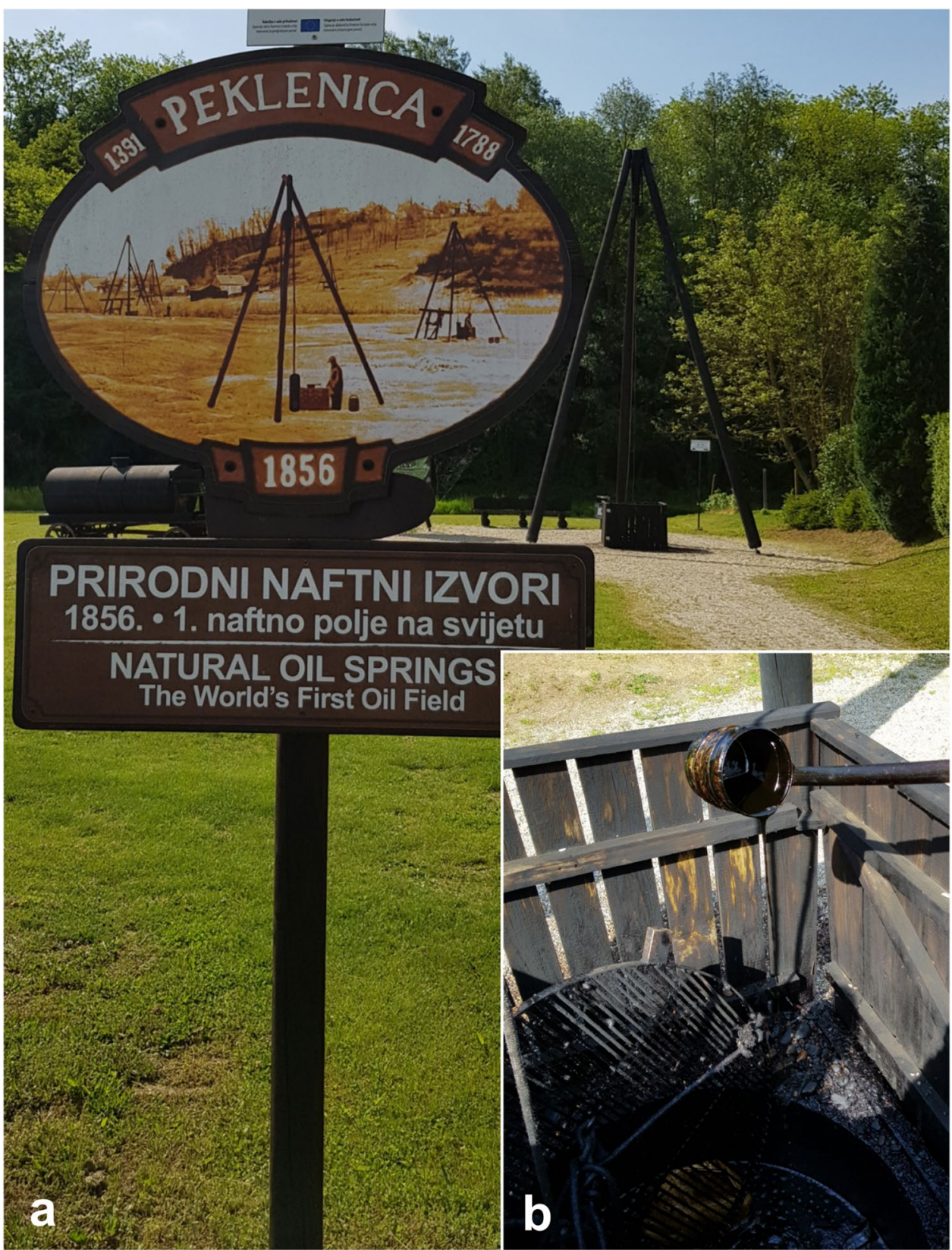


Raky's Hill, where the main oil horizon is located at a depth of 127-145 m. Petroleum was commonly used for lighting (Križ et al. 2008).

The Peklenica and Selnica Petroleum Heritage Park is a part of the Mining-Mura Road, which is a positive example of promoting mining heritage in the area of Mursko Središće (URL11 2021). Mining-Mura Road is located near the Mura-Drava Regional Park and is part of the Mura-Drava-Danube Transboundary Biosphere Reserve. The purpose of the project is to acquaint the users of this road with the history of the city, its mining past and the importance of the Mura River for the entire area, as well as to encourage the local population to participate in recreation. The positive side of this project is connecting different types of tourism for the purpose of promoting petroleum and mining heritage-merging recreational (river promenade and bicycle trail) and cultural (visit to historical sites, info boards with an educational content) tourism. The MiningMura Road is 12-km-long and it takes about four hours of walking to cross the entire trail. In this case, an important factor was the blending of this site with other tourist offers or routes (cultural or recreational). That was proven to be of great significance, especially since the site and the route are surrounded by beautiful landscapes.

\section{Methodology for Case Study Analyses}

A SWOT analysis is a management tool commonly used for geoconservation and geotourism in one location or in a smaller area (Kalantari et al. 2011; Carrión Mero et al. 2018; Datta 2020), but in this paper, it was necessary to analyze four sites throughout the national territory. Thus, by adapting the research technique, a response was made to the question of the application of SWOT analysis under such specific conditions. A brief recapitulation of the research methodology is shown graphically in Fig. 6.

After selecting the four best cases, an SWOT analysis was conducted to determine the strengths, weaknesses, opportunities, and threats of the selected sites. Strengths represent internal factors that have a positive influence on revitalization processes and can promote geotourism as a form of natural area tourism. Opportunities are regarded as external factors that add value to the revitalization processes of sites. Weaknesses are all internal factors that represent obstacles on revitalization processes and have a negative impact on it, while threats are external negative factors that represent risks in revitalization processes.

A TOWS matrix was created to allow for the formation of multiple sub-strategies. The sub-strategies within the TOWS matrix are based on an appropriate combination of factors representing strengths, weaknesses, opportunities and threats. The goal is to create more appropriate sub-strategies

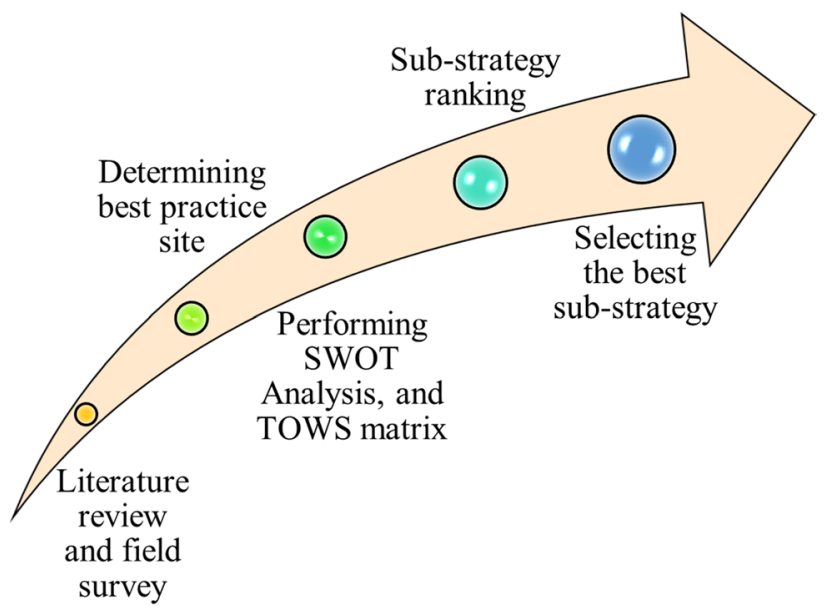

Fig. 6 Research methodology diagram

within the four general strategies of the TOWS matrix. The maxi-maxi strategy (SO) explains how forces can be used to realize certain opportunities. The maxi-mini strategy (ST) is essentially based on the effort to use all resources to minimize or eliminate threats. Mini-maxi strategy (WO) is about overcoming weaknesses to realize certain opportunities. Mini-Mini (WT) is a very defensive strategy that aims to minimize weaknesses and avoid threats (Antić and Tomić 2017).

Sub-strategy ranking was done through principles of geotourism that were identified by Dowling (2011). He listed five basic principles of geotourism: geologically based, sustainable, geologically informative, locally beneficial, and tourist satisfaction. The geologically based principle is essential to planning, development, and management, and essentially means it has a focus on the earth and its geological features from rock outcrops to entire landscape vistas. The sustainable principle means that geotourism must foster economic viability, community enhancement and geoconservation. By applying geologically informative principles, with the help of earth education and geo-interpretation, it encourages geotourism to attract people who wish to interact with the earth environment in order to develop their knowledge, awareness and appreciation of it. The locally beneficial principle means that the involvement of local communities does not only benefit the community and the environment, but also improves the quality of tourist experience. Local communities can become involved in geotourism operations and the provision of knowledge, services, facilities and products. The tourist satisfaction principle seeks to make both general "visitors" and tourists ranging from geo-amateurs to geo-experts satisfied with a particular geological heritage (Dowling 2011).

The authors of this paper ranked sub-strategies based on the assessment of how much a particular sub-strategy 
contributes to a particular principle of geotourism. The evaluation methodology is shown in Table 2.

However, it should be taken into account that this is a subjective method, and each actor has evaluated individual sub-strategies separately. In the end, the best sub-strategies were selected according to the total number of points they collected. The ranking of sub-strategies was performed on a simple principle than to the previous paper of Datta (2020), when used the most ideal method to devise an optimal decision called the Analytical Hierarchy Process (AHP). However, even the most ideal model AHP is very much subjective in nature (Datta 2018).

Table 2 Evaluation methodology of sub-strategy

\begin{tabular}{ll}
\hline Numerical grade & Explanation ratings \\
\hline 1 & $\begin{array}{l}\text { Sub-strategy has an immediate positive } \\
\text { impact on some principle of geotour- } \\
\text { ism } \\
\end{array}$ \\
0 & Sub-strategy has no impact or is neutral \\
-1 & Sub-strategy has an immediate negative \\
& impact on some principle of geotour- \\
& ism \\
\hline
\end{tabular}

\section{Results and Discussion}

A SWOT analysis was performed for four case studies in Croatia. The current state of strengths and weaknesses, future opportunities, and possible threats to which this type of cultural and natural heritage might be exposed is presented in Table 3. The order of internal effective factors is set according to the contribution they can make to help preserve the geological heritage and to promote geotourism. Weaknesses are ranked according to the most significant obstacles to the development of geotourism and the protection of this type of heritage. Opportunities (i.e., externally favorable conditions that can be exploited) and external negative factors that create barriers and increase risks in geotourism and heritage protection are also ranked similarly.

A TOWS matrix (Table 4) has been performed to develop four major strategies according to SWOT analysis. Strengths, weaknesses, opportunities, and threats were combined into nine sub-strategies.

After the TOWS matrix was developed, the sub-strategies were evaluated according to their contribution to each of the five principles of geotourism through the evaluation methodology from Table 2. To ensure methodological correctness, each author conducted his or her independent subjective assessment of contributions, after which the points were summed up and shown in Table 5. The number of points conditioned the ranking of the sub-strategies into seven ranks. SO1 ranked first by 14 points while WT3 ranked

Table 3 SWOT analysis of case-study heritage sites in Croatia

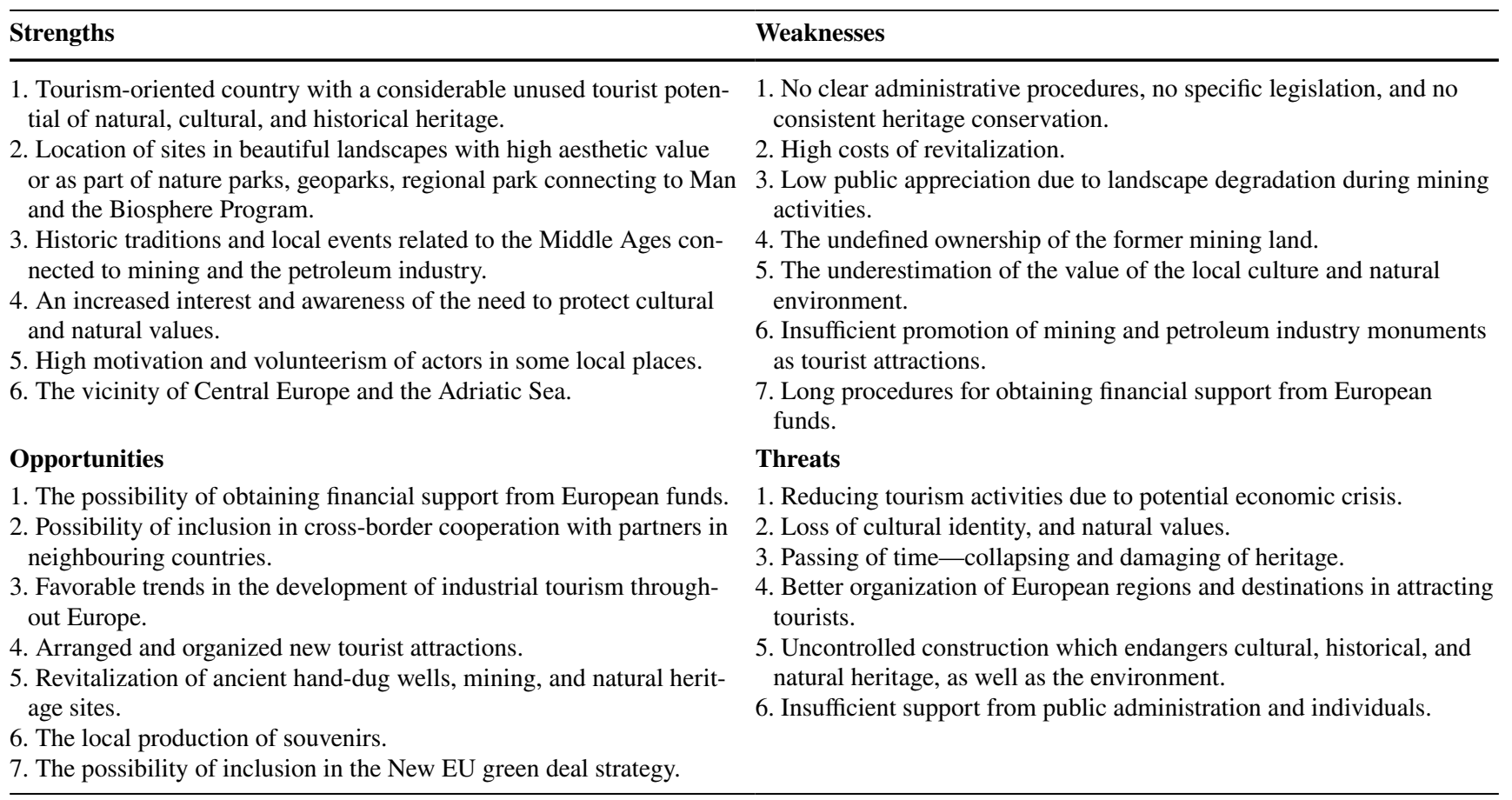


Table 4 TOWS matrix based on SWOT analysis

\section{Strengths + opportunities (maxi-maxi)}

SO1-Development of cultural and natural tourism referring to the $3 \times E$ rule (education, entertainment, and excitement) with orientation on the principles of geotourism. That will help in changing the negative perception of mining activities into something positive, useful, and important for the development of the human society.

SO2-Financial support from European funds must be used for the protection of natural, cultural, and historical heritage with a special focus on historical traditions and local events. That can be particularly suitable if heritage is a part of nature parks, geoparks or regional parks.

\section{Strengths + threats (maxi-mini)}

ST1-Collecting artefacts and stories about historic traditions, and the production of local souvenirs connected to the mining and petroleum industry, will minimize the loss of cultural identity and natural values, and help to gap the insufficient support of public administration and individuals.

ST2-Protection of industrial sites will prevent the collapsing and damaging of heritage and will help to stop the loss of local community identity.
Weaknesses + opportunities (mini-maxi)

WO1-Arranged and organized new tourist attractions with the involvement of the local population will result in the high promotion of mining monuments and the petroleum industry as tourist attractions. This will increase support for geoheritage conservation in general.

WO2-Cross-border cooperation in the promotion of geoheritage associated with the mining and petroleum industry monuments will increase the number of tourist attractions and visibility. This can be further enhanced by the advantage of the vicinity of Central Europe and the Adriatic Sea.

\section{Weaknesses + threats (mini-mini)}

WT1-Create mutually harmonized framework laws and clear sustainable procedures for the use of geological heritage for educational and tourism purposes will shorten the time of administrative and technical work.

WT2-Maximum involvement of the local people will strengthen the public support needed to preserve heritage and reduce its underestimation.

WT3-EU regulation regarding green energy will reduce mining activities and some sites will be suitable for the European funds support to reuse them as a cultural heritage.
Table 5 The result of the scoring and ranking of substrategies

\begin{tabular}{|c|c|c|c|c|c|c|c|c|c|c|}
\hline \multirow[t]{2}{*}{ Principles of geotourism } & \multicolumn{10}{|c|}{ Sub-strategies } \\
\hline & SO1 & $\mathrm{SO} 2$ & WO1 & WO2 & ST1 & ST2 & WT1 & WT2 & WT3 & $\Sigma$ \\
\hline Geologically based & 3 & 2 & 1 & 2 & 0 & 2 & 1 & 2 & 1 & 14 \\
\hline Sustainable & 2 & 2 & 1 & 2 & 2 & 0 & 3 & 2 & 1 & 15 \\
\hline Geologically informative & 3 & 0 & 2 & 2 & 3 & 0 & 2 & 1 & 0 & 13 \\
\hline Locally beneficial & 3 & 3 & 3 & 3 & 3 & 3 & 3 & 3 & 2 & 26 \\
\hline Tourist satisfaction & 3 & 1 & 3 & 3 & 1 & 1 & 3 & 2 & 0 & 17 \\
\hline$\Sigma$ & 14 & 8 & 10 & 12 & 9 & 6 & 12 & 10 & 4 & \\
\hline Rank & 1. & 5. & 3. & 2. & 4. & 6. & 2. & 3. & 7. & \\
\hline
\end{tabular}

last with 4 points. Two sub-strategies scored 12 points and ranked second, namely WO2 and WT1, while WO1 and WT2 each have 10 points and ranked third. ST1 ranked fourth, followed by SO2 and ST2 sub-strategies individually.

The authors of this paper applied a ranking methodology that is strongly related to the principles of geotourism. Additional objectivity was emphasized by the introduction of an independent evaluation of all three authors whose grades were summed up and on that basis the ranking of sub-strategies was performed. With this the authors put importance on simplicity and on connecting sub-strategies with the principles of geotourism. Based on the results in Table 5, a diagram was made (Fig. 7), which shows how much each principle of geotourism participates in the evaluation. The

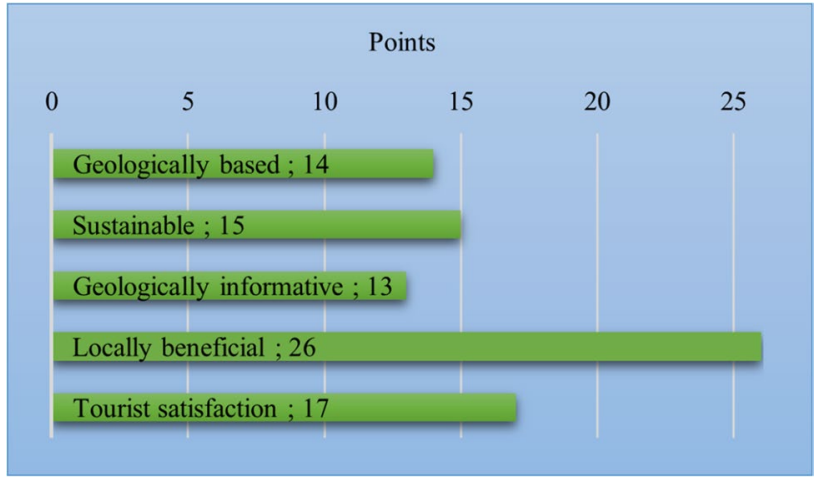

Fig. 7 The number of points for proposed principles of geotourism 
highest possible score is 27 points (this would happen if every researcher found that all sub-strategies contribute to this principle). The locally beneficial principle came closest to this number. The tourist satisfaction and sustainable principles also have a good share. By combining two geological principles (geologically based and geologically informative), the maximum of 27 points was gained. These two principles are mutually connected, one must include the other and vice versa. Based on this, it can be argued that a simple methodology has achieved the successful formation and ranking of sub-strategies that will connect geoheritage to geotourism.

\section{Main Attributes of SWOT Analysis and TOWS Matrix}

SWOT analysis has proven to be a good starting point for making decisions for new purposes and directions of revitalization. During revitalization, many aspects (strengths and opportunities, weaknesses, and threats-as listed in Table 3) need to be considered. Accordingly, the right decision about the possibilities of future revitalization can be made and the most sustainable solution for their new life can be found.

The presentation of geological heritage has a major role in geotourism because it plays an important part in the protection of nature. All our geological and petroleum heritage locations are particularly suitable for the development of industrially oriented tourism and geotourism with the $3 \times \mathrm{E}$ rule. Besides, local authorities together with local tourist offices have a crucial role in the preservation and management of geological heritage as witnessed in the cases of St. Barbara Mine, Zrinski Mine, and Rupnica Quarry. Increased interest and awareness of the need to protect cultural and natural values together with high motivation and volunteerism of actors in some local places has been noted, as in all our best cases. Peklenica and Selnica Petroleum Heritage Park is part of Mining-Mura Road that has remains and traces of exploitation which turned into tourist activities. Furthermore, applying for European funds has proven to be a key factor in the revitalization of such places, as shown in the case of St. Barbara Mine.

At the same time, the number of historic traditions and local events related to the Middle Ages and connected to the mining and petroleum industry (Days of Miners' cake in St. Barbara Mine, Medieval days on Medvednica near the Zrinski Mine) and the production of souvenirs is increasing. Our four sites are located in beautiful landscapes with high aesthetic value, or they are part of nature parks (Zrinski Mine), geoparks (Rupnica Quarry), regional parks connected to the Man and the Biosphere Program, which benefits the sites.

The revitalization processes of old mining sites could also be affected by many current weaknesses and possible threats in the future. Revitalization in most cases is influenced by undefined ownership of the raw land where the mining operations were performed. The state often represents the formal owner of the land, but it does not recognize its potential. That is related to the question of inadequate legal framework and administrative procedures pertaining to the issue. There is no consistent heritage conservation which relates to administrative and legislative problems, but also the high costs of revitalization. As well, in many regions low public support of mining activities can also affect revitalization processes. That is also a result of the insufficient promotion of mining and petroleum industry monuments as tourist attractions and the underestimation of the local culture and natural environment. The biggest threats are the possibility of economic crisis and expected decline in tourist activity, such as the current COVID-19 crisis. The COVID-19 crisis will certainly aggravate the situation in tourism in the short term, and thus currently reduce the investment in terms of protecting cultural heritage, not only in Croatia, but in other countries as well. A longer-term threat represents the passing of time because heritage is slowly collapsing, and many mines could in fact become risky and dangerous places instead of becoming places suitable for visitors. That can also affect the increase in loss of cultural and historical identity. In addition, a lack of financial support and difficult and arduous procedures for obtaining European funds can also negatively influence the decision to start with the realisation of revitalization projects. Particularly, there is strong competition from other regions and destinations in terms of applying for funding. That problem can be even bigger without the support from the public administration and individuals, either on a local or regional level. To overcome threats and weaknesses and to boost strengths and opportunities, nine sub-strategies were determined by the TOWS matrix (Table 4).

The primary goal of every devised sub-strategy (Table 4) is to increase general support for geoheritage conservation. Maximum involvement of the local people can strengthen the public support to preserve heritage, and help in reducing its underestimation. In addition, high promotion of mining monuments and the petroleum industry as tourist attractions can minimize the loss of cultural identity and natural values, and help close the gap between the insufficient support of public administration and individuals. Once people's attitude to mining is changed, the revitalization process of mines can be more in focus. Instead of looking at mining as something ugly and unpleasant, it can be turned into something useful, vital, valuable, and important for the development of human society. Because of negative perceptions of mining and post-industrial landscapes in general (Kaźmierczak et al. 2017), the cultural preservation of mining heritage should be more orientated to geotourism, mining traditions, customs, and unique local identities. 


\section{Strategy Ranking}

According to sub-strategy ranking in TOWS matrix, the SO1 sub-strategy concerning development tourism referring to the $3 \times \mathrm{E}$ rule with orientation on principles of geotourism ranked first. That means that all five principles of geotourism were included and positively evaluated; hence, SO1 sub-strategy gained 14 out of 15 points (Fig. 8). Such a maxi-maxi strategy is oriented to changing the negative perception of mining activities into something positive, useful, and important for the development of human society. Remarkably, WT1 sub-strategy, which contributes the most to overcome weaknesses and threats (mini-mini strategy), is ranked second. That indicates the importance of legislations and clear sustainable procedures for revitalization processes, which is the main problem in Croatia. Besides the lacking legislations for revitalization, in many situations, state and local legislature bodies are not always fast and efficient. The WO2 sub-strategy (also second ranking) can be closely linked to the SO1 sub-strategy where cross-border cooperation in the promotion of geoheritage associated with mining and petroleum industry monuments play an important part. That is evidenced in Peklenica and Selnica Petroleum Heritage Park which is part of the Mura-Drava-Danube Transboundary Biosphere Reserve. Theoretically, connecting the first three sub-strategies (ranked as first and second) can be applied simultaneously to maximize the positive effect. However, the same dynamics of implementation of every strategy cannot be expected. Mini-mini sub-strategy WT3 was ranked seventh, while the maxi-mini strategy ST2

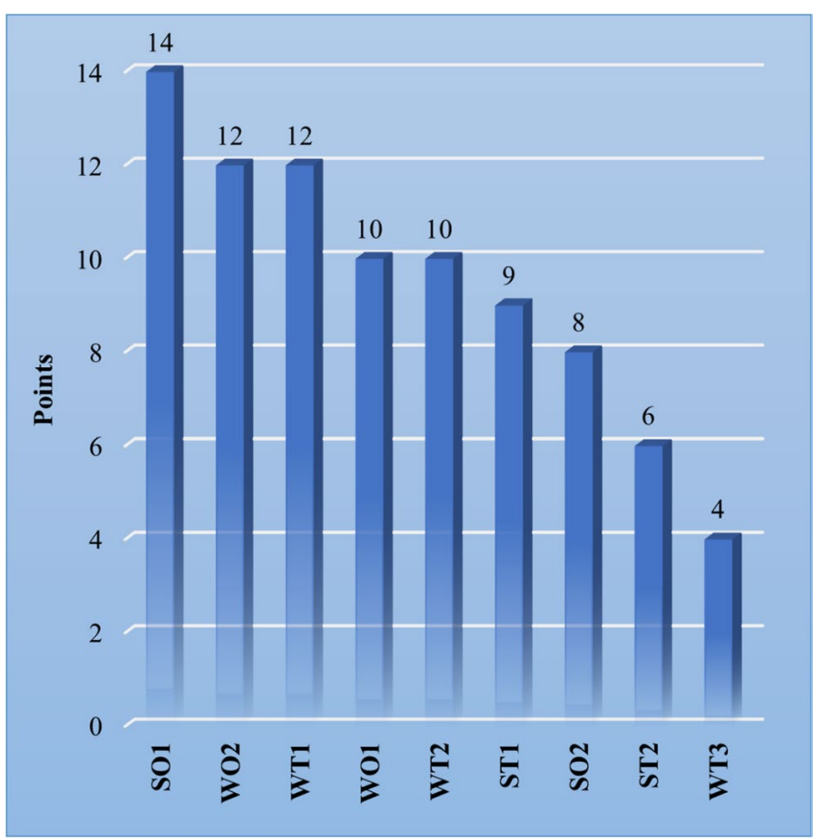

Fig. 8 Score of all sub-strategies in TOWS matrix ranked sixth according to the main principles of geoheritage. However, blending these two strategies through new EU regulation regarding green energy will help in stopping the collapsing and damaging of heritage and consequently, the loss of local community identity.

Regardless of ranking, each sub-strategy is important for revitalization processes. In order to maximally overcome threats and weaknesses, it would be preferable not to be oriented only on one strategy, but to combine more strategies as one. In this way, revitalization would be more efficient and successful. Regarding every sub-strategy, it is important that revitalization and geoheritage protection contain a strong informative and educational component. Visitors would thus appreciate the value of geoheritage, the importance of mineral resources for human civilization, environmental protection, and the hard work of miners.

\section{Conclusion}

Nowadays, Croatia can be considered as a poor-mining country, mostly tourism-oriented with a considerable tourist potential due to the vicinity of Central Europe and the Adriatic Sea. During the past, Croatia was a more active mining country, where different raw materials and hydrocarbons were exploited, with stone as the predominant material. Many places abandoned after their exploitation could be revitalized and used for tourist purposes as a part of a geotourist potential. Contemporary world trends promote a new form of tourism that is mostly oriented to the $3 \times \mathrm{E}$ rule (education, entertainment and excitement) instead of the usual model referred to as $3 \times \mathrm{S}$ (sun, sea, and sand). Especially nowadays, favorable trends have been noticed in the development of industrial tourism and related geotourism through the revitalisation of ancient hand-dug wells and mining throughout Europe. That can be a benefit to the local authorities to learn from European good practice and to apply it on a local level. Site revitalization avoids old facilities decommissioning costs which have to be removed due to security reasons. Decommissioning refers to the administrative and technical activities taken to remove the whole site. Therefore, the mentioned cost could be repurposed for geotourism promotion.

Based on the order of sub-strategies resulting from the analysis of four best-case studies in Croatia, some important facts should be highlighted:

- The analysis in this paper has shown that the highest scoring sub-strategy is SO1, which involves developing tourism according to the $3 \times \mathrm{E}$ rule in line with the principles of geotourism. This proves that currently, poormining states can set up strategies to protect, present, and promote their former industrial heritage, which is related 
to geoheritage, and include it in intensively developing modern tourism with the $3 \times \mathrm{E}$ rule and strong educational component.

- The second ranked sub-strategy WT1 proves that weaknesses and threats could most likely be reduced by creating mutually harmonized framework legislation and clear sustainable procedures for the use of the geological heritage for educational and tourism purposes. Similarly, WT2 demonstrates that the best way to reduce weaknesses is through transboundary cooperation in the promotion of geological heritage related to mining and petroleum industrial monuments.

- Synergies between all stakeholders, local authorities and volunteers in all best-cases (Rupnica Quarry, St. Barbara and Zrinski Mine, Peklenica and Selnica Petroleum Heritage Park) are essential for project success during the revitalization process.

- Important factors that have an impact on the revitalization processes are tangible ones, like revitalization costs and applying for European funds (St. Barbara Mine).

- Whether it is different types of heritage, such as industrial heritage (mining and petroleum) or geological heritage related to mining, an appropriate and innovative way of revitalization can be found. Best practice examples could potentially be recognized as some other European cases.

Acknowledgements This paper is supported by the project "MineHeritage: Historical Mining-Tracing and Learning from Ancient Materials and Mining Technology" funded by the European Institute of Innovation and Technology (EIT), a body of the European Union, under the Horizon 2020, the EU Framework Programme for Research and Innovation. It is also supported by the project "The analysis of Croatian mining and petroleum heritage with case studies-MPG_HE" funded by the University of Zagreb, Faculty of Mining, Geology and Petroleum Engineering.

\section{References}

Antić A, Tomić N (2017) Geoheritage and geotourism potential of the Homolje area (eastern Serbia). Acta Geoturistica 8(2):67-78. https://doi.org/10.1515/agta-2017-0007

Baczyńska E, Lorenc MW, Kaźmierczak U (2018a) The landscape attractiveness of the abandoned quarries. Geoheritage 10:271285. https://doi.org/10.1007/s12371-017-0231-6

Baczyńska E, Lorenc MW, Kaźmierczak U (2018b) Research on the landscape attractiveness of the selected abandoned quarries. Int J Min Reclam Environ 32/6:401-419. https://doi.org/10.1080/ 17480930.2017.1386756

Balen D, Petrinec Z (2013) Development of columnar jointing in albite rhyolite in a rapidly cooling volcanic environment (Rupnica, Papuk Geopark, Croatia). Terra Nova 26(2):102-110. https://doi. org/10.1111/ter.12075

Belamarić D (2006) Park prirode Medvednica (Medvednica Nature Park - in Croatian). Eko revija, Glasilo Fonda za zaštitu okoliša i energetsku učinkovitost 10:55-57
Briševac Z, Maričić A, Brkić V, Bralić V (2021) An overview and future prospects of Croatian geotechnological heritage. MinGeol-Pet Bull 36(1):77-97. https://doi.org/10.17794/rgn. 2021.1.7

Budak N (1994) Rudnik u Rudama kraj Samobora od XV. do kraja XVII. Stoljeća (Mine in Rude near Samobor from the XV to the end of XVII Century - in Croatian). Radovi - Filozofski fakultet Sveučilišta u Zagrebu, Zavod za hrvatsku povijest 27:75-97

Carrión Mero P, Herrera Franco G, Briones J, Caldevilla P, Domínguez-Cuesta MJ, Berrezueta E (2018) Geotourism and Local Development Based on Geological and Mining Sites Utilization, Zaruma-Portovelo, Ecuador. Geosciences 8:205. https:// doi.org/10.3390/geosciences8060205

Cheirchanteri G (2019) Industrial Cultural Heritage as an Alternative Tourism Model: Case study of the Wider Lavreotiki area in Southeastern Attica. IOP Conf Ser: Mater Sci Eng 603:022001. https:// doi.org/10.1088/1757-899X/603/2/022001

Crnički J, Sinkovec B (1993) Nemetalne mineralne sirovine Hrvatske (Non-metallic minerals in Croatia - in Croatian). Min-Geol-Pet Eng Bull 5(1):21-37

Crnković B, Jovičić D (1993) Dimension stone deposits in Croatia. Min-Geol-Pet Eng Bull 5:139-163

Datta K (2018) Geo-environmental analysis and management of Pagla river basin, part of Jharkhand and West Bengal with special reference to water logging: a study in applied geomorphology, $\mathrm{Ph}$. D. Thesis, Visva-Bharati, p 169. http://shodhganga.inflibnet.ac.in: 8080/jspui/handle/10603/216452. Accessed 10 Apr 2021

Datta K (2020) Application of SWOT-TOWS Matrix and Analytical Hierarchy Process (AHP) in the Formulation of Geoconservation and Geotourism Development Strategies for Mama Bhagne Pahar: an Important Geomorphosite in West Bengal, India. Geoheritage 12:45. https://doi.org/10.1007/s12371-020-00467-2

Dowling RK (2011) Geotourism's global growth. Geoheritage 3(1):113. https://doi.org/10.1007/s12371-010-0024-7

Festin ES, Tigabu M, Chileshe MN, Syampungani S, Odén PC (2019) Progresses in restoration of post-mining landscape in Africa. $\mathrm{J}$ For Res 30:381-396. https://doi.org/10.1007/s11676-018-0621-x

Fio Firi K, Maričić A (2020) Usage of the Natural Stones in the City of Zagreb (Croatia) and Its Geotouristical Aspect. Geoheritage 12:62. https://doi.org/10.1007/s12371-020-00488-x

Inácio N, Ferreira T, Oliveira M, Pinto AMM, Relvas JMRS (2013) The megalithism in Lousal: an example of valorisation of mining, geological and archaeological heritage. XIV Congreso sobre Patrimonio Geológico y Minero. Castrillón (Asturias), 2013. LIBRO DE ACTAS DEL CONGRESO, pp 743-755. http://www.sedpg ym.es/18-publicaciones/actas-congresos/76-actas-del-xiv-congr eso-internacional-sobre-patrimonio-geologico-y-minero-xviiisesion-cientifica-de-la-sedpgym-castrillon-2013. Accessed 10 Apr 2021

Jelen J (2018) Mining heritage and mining tourism. Czech J Tourism 7/1:93-105. https://doi.org/10.1515/cjot-2018-0005

Jug N, Barudžija U, Durn G (2008) Distribucije Hg u zraku tla i Hg u tlu oko napuštenog rudnika "Zrinski" na Medvednici (Hgsoil gas and $\mathrm{Hg}$ soil distribution around former "Zrinski" mine on Mt. Medvednica - in Croatian). Min-Geol-Pet Eng Bull 20(1):1-11

Kalantari M, Bazdar F, Ghezelbash S (2011) Feasibility analysis of sustainable development emphasizing geotourism attractions using SWOT analysis. Case Study: Qeshm Island GeoPark, 24th edn. In International Conference on Biology, Environment and Chemistry, Singapore, pp 181-187

Kaźmierczak U, Lorenc MW, Strzałkowski P (2017) The analysis of the existing terminology related to a post-mining land use: a proposal for new classification. Environ Earth Sci 76:693. https://doi.org/ 10.1007/s12665-017-6997-7

Kaźmierczak U, Strzałkowski P, Lorenc MW, Szumska E, Peréz Sánchez AA, Baker KAC (2019) Post-mining Remnants and 
Revitalization. Geoheritage 11:2025-2044. https://doi.org/10. 1007/s12371-019-00408-8

Križ J, Weisser M, Brkić V, Domitrović D, Ivković Ž (2008) Istraživanje i proizvodnja nafte i plina u Hrvatskoj i u inozemstvu (Oil and gas exploration and production in Croatia and abroad - in Croatian). Nafta 59(5):261-267

Kruczek Z, Kruczek M (2016) Post-industrial tourism as a means to revitalize the environment of the former oil basin in the Polish Carpathian Mountains. Pol J Environ Stud 25/2:1-6. https://doi. org/10.15244/pjoes/61241

Laszowski E (1942) Rudarstvo u Hrvatskoj, svezak 1 (Mining in Croatia, Volume 1 - in Croatian). Hrvatska državna tiskara, Zagreb, p 182

Laszowski E (1944) Rudarstvo u Hrvatskoj, svezak 2 (Mining in Croatia, Volume 2 - in Croatian). Hrvatska državna tiskara, Zagreb, p 258

Laurence D (2011) Establishing a sustainable mining operation: an overview. J Clean Prod 19:278-284. https://doi.org/10.1016/j. jclepro.2010.08.019

Learned EP, Christensen CR, Andrews KR, Guth WD (1969) Business policy: text and cases. RD Irwin, Homewood, p 838

Limpitlaw D, Briel A (2014) Post-mining land use opportunities in developing countries-a review. J Southern Afr Inst Min Metall 114(11):899-903

Lugović B, Šegvić B, Altherr R (2006) Petrology and tectonic significance of greenschists from the Medvednica Mts. (Sava Unit, NW Croatia). Ofioliti 31(1):39-50. https://doi.org/10.4454/ofiol iti.v31i1.32

Marušić R, Sakač K, Vujec S (1993) Four centuries of bauxite mining. Min-Geol-Pet Eng Bull 5(1):15-20

Mborah C, Bansah KJ, Boateng M (2016) Evaluating alternate postmining land-uses: a review. Environ Pollut 5/1:14. https://doi.org/ 10.5539/ep.v5n1p14

Mileusnić M, Maričić A, Hruškova Hasan M (2019) Croatian geological heritage related to historical mining and quarrying. Eur Geol J 48:5-9

Palinkaš L, Borojević Šoštarić S, Strmić Palinkaš S, Prochaska W, Spangenberg J, Cuna S, Šinkovec B (2010) Permian- polysulphide-siderite-barite-haematite deposit Rude in Samoborska Gora Mts., Zagorje-Transdanubian zone of the Inner Dinarides. Geol Croatica 63(1):93-115

Pardo Abad CJ (2017) The post-industrial landscapes of Riotinto and Almadén, Spain: scenic value, heritage and sustainable tourism. J Herit Tour 12(4):331-346. https://doi.org/10.1080/1743873X. 2016.1187149

Paunović M (1996) National List of the protected natural sites in Croatia. Geol Balc 26/1:69-71

Petrić H (2011) Samobor i okolica u ranome novom vijeku (Early Modern Samobor- in Croatian). In: Feletar D (ed) Samobor. Zemljopisno-povijesna monografija, Meridijani, pp 237-321

Rybár P, Hronček P (2017) Mining tourism and the search for its origins. Geotourism 3-4:27-66. https://doi.org/10.7494/geotour. 2017.50-51.3

Šebečić B (1995) The history of the exploration and exploitation of bituminous and kerogenous deposits in Croatia. Min-Geol-Pet Eng Bull 7(1):97-130
Šinkovec B (1971) Geologija ležišta željezne i bakrene rude u Rudama kraj Samobora (Geology of iron and copper ore deposit at Rude near Samobor - in Croatian). Geološki vijesnik 24:165-181

Šinkovec B, Palinkaš L, Durn G (1988) Rudne pojave Medvednice (Ore occurrences on the Medvednica Mountain - in Croatian). Geol Vjesn:41395-41405

URL1 (2021) UNESCO World Heritage List https://whc.unesco.org/ en/list/?search=mining\&order=country. Accessed 23 Apr 2021

URL10 (2021) Nature Park Medvednica, Zrinski Mine https://www. pp-medvednica.hr/en/tourist-offer/zrinski-mine/. Accessed 24 Apr 2021

URL11 (2021) Mining-Mura Road http://www.tz-ms.hr/turistickivodic/rudarsko-murski-put/. Accessed 28 Mar 2021

URL2 (2021) European Route of Industrial Heritage https://www.erih. net/. Accessed 14 Mar 2021

URL3 (2021) MineHeritage Project https://mineheritage-project.eu/. Accessed 3 Mar 2021

URL4 (2021) Geopark Vis Archipelago https://geopark-vis.com/en. Accessed 3 Aug 2021

URL5 (2021) Croatian Folklore Ensemble Oštrc https://www.ostrc.hr/ rudnici.html. Accessed 3 Aug 2021

URL6 (2021) Nature park Papuk https://pp-papuk.hr/?lang=en. Accessed 14 Mar 2021

URL7 (2021) St. Barbara Mine. http://www.rudnik.hr/. Accessed 24 Apr 2021

URL8 (2021) Hologram of Bergman in the St. Barbara Mine https:// www.holofiction.hr/en/company/projects/hologram-in-the-cave. html. Accessed 3 Aug 2021

URL9 (2021) Register of Cultural Property of the Republic of Croatia https://min-kulture.gov.hr/register-of-cultural-property/16777. Accessed 24 Apr 2021

Vasiljević R, Fabijanec SF (2016) L'exploitation et le commerce des metaux en Croatie \& Slavonie médiévales - Esquisse d'une recherche. Ekonomska i ekohistorija 12(1):65-100

Vrkljan D (2019) Zaštita hrvatske rudarsko-geološke materijalne baštine (Protection of Croatian mining-geological material heritage - in Croatian). Annu Croatian Acad Eng 2019(1):485-500

Vujec S (1996) Rudarstvo u Hrvatskoj (The Mining industry of Croatia - in Croatian). Min-Geol-Pet Eng Bull 8(1):11-17

Weihrich H (1982) The TOWS Matrix a tool for situational analysis. Long Range Plan 15(2):54-66. https://doi.org/10.1016/00246301(82)90120-0

Žeger Pleše I, Zwicker Kompar G (2019) Geoheritage in Croatia yesterday, today and tomorrow. Acta Geogr Croat 45/46(1):1-13. https://doi.org/10.21861/AGC.2019.45-46.01

Žgaljić J (1984) Nafta na našem tlu. Razvoj naftne privrede (Oil in our area. Development of petroleum industry - in Croatian). Privredni vjesnik, Zagreb, p 283

Zwicker G, Žeger Pleše I, Zupan I (2008) Zaštićena geobaština Republike Hrvatske (Protected Geo-heritage of the Republic of Croatiain Croatian). Državni zavod za zaštitu prirode, Zagreb 